\author{
FRANCESCO BERTI \\ ORCID: 0000-0002-6493-6516 \\ Università di Padova
}

\title{
Augusto Del Noce and the problem of totalitarianism
}

The aim of this paper is to briefly present the reflections of the Italian philosopher Augusto Del Noce on totalitarianism and highlight some of the problems that this perspective can lead to in the analysis of the totalitarian phenomenon and of the liberal and democratic societies that effectively have struggled against it.

Augusto Del Noce (1910-1989) was one of the greatest Italian philosophers of the $20^{\text {th }}$ Century and a distinguished historian of philosophy. After becoming fascinated by left-wing Catholicism, at the end of World War II he reviewed his thinking and came to embrace an "integral" Catholicism. Del Noce was against both to the "historic compromise" that was the strategic alliance between the party of the Christian Democrats and the Communists and to a half-measure between Christian philosophy and neo-Enlightenment. He originally developed a philosophical and "transpolitical" interpretation of modernity and secularization in a lot of his works, some of which I am going to quote here.

A "politically incorrect" thinker, a traditionalist Catholic in a period in which the left-wing exerted a cultural hegemony in Italy, covering up errors and horrors of Communist regimes with anti-Fascist ideology, Del Noce developed an original and critical interpretation of totalitarianism. He pre-empted, in the early $1960 \mathrm{~s}$, many of the arguments developed, in the following years, by historians such as Ernst Nolte and Renzo De Felice, and by historians of political thought such as Domenico Settembrini, with whom he later had a fruitful dialog.

Before going into detail, I would like to draw attention to the most original aspects of his interpretation of contemporary history. In my view, they can be summarized in the following points. Firstly, for Del Noce history is, in many respects, a product of philosophy — this is exactly his trans-political nature ${ }^{1}$ — and

${ }^{1}$ A. Del Noce, Secolarizzazione e crisi della modernità, Napoli 1989, pp. 12, 64. Del Noce took the expression from De Felice, but applies it to all contemporary history, not just to Fascism. 
therefore it is possible to reconstruct the genesis of $20^{\text {th }}$ Century totalitarianism purely with a philosophical method. Del Noce underlines that in the works of Nolte and De Felice he found the same thesis which he had achieved some years before, in a theoretical way. ${ }^{2}$ This perspective has a very significant interpretative implication, because for the Italian philosopher history has a rational development that connects the different currents of thought and the world of thought to that of material facts often following the principle of cause and effect.

Secondly, from this point comes the idea that totalitarianism, as a regime not only Fascist and Nazi, but also the Communist one - cannot be understood as a change in direction from its philosophical roots. However - in the case of Communism - it can be seen only with respect to its expectations, constituting, on the other hand, the more consistent, logical, rational and necessary haven of such beginnings. Totalitarianism, writes Del Noce, was not "a response to the historical contingency", but finds its roots "in a certain way of exploring the political function in the life of the spirit" 3 and especially in the "raising up of politics and religion". 4

Thirdly, Del Noce believes that the most perfect form of totalitarianism was that of Communism. Compared to this, Nazism appears a symmetric and opposite reaction, which was triggered from the outside and therefore presents a theoretical weakness, being completely dependent on Marxist-Leninist ideology. ${ }^{5} \mathrm{He}$ considers Fascism an under-developed and spurious variant of totalitarianism, since it started, like Nazism, as a form of kickback to Communism. Fascism, however, grew out of a revolutionary leftist ideology cloaked by nationalism - the Fascism of Mussolini - and was supported by a philosophy of praxis - the Fascism of Giovanni Gentile - that explicitly aspired to make truth ("inverare") Marxism in a purely and not materialistic form of immanentism, separating dialectic and materialism. Therefore Del Noce finds in Fascism a "heresy of Communism". 6 On a theoretical level, there is Mussolini's corruption of revolutionary Socialism with

${ }^{2}$ For the agreement with Nolte, especially with the philosophical interpretation of contemporary history, and with the concept of a "1917-1945 European civil war", see in particular A. Del Noce, op. cit., p. 9; idem, Giovanni Gentile. Per una interpretazione filosofica della storia contemporanea, Bologna 1990, p. 11. Above all, Del Noce shared with Nolte the interpretation of totalitarian Nazism and Fascism as reactions ("contraccolpi") to Marxism and the Bolshevik Revolution. See idem, Il problema dell'ateismo, Bologna 2010, p. 557. With regard to De Felice's interpretation of Fascism as a political movement against the bourgeoisie with strong left-wing roots, see A.J. Gregor, A. Del Noce, R. De Felice, "Dibattito sulla natura del Fascismo", [in:] R. De Felice, Fascismo, Firenze 2011, pp. 90-93, 98-99. On Del Noces's revisionism you can see M. Veneziani, "Del Noce filosofo del revisionismo in Italia", [in:] Aa.Vv., Augusto Del Noce. Il problema della modernità, Roma 1995, pp. 107-125.

3 A. Del Noce, Il problema dell'ateismo, p. 32.

4 A. Del Noce, "Problemi della democrazia", [in:] idem, Scritti politici 1930-1950, ed. T. Dell'Era, Soveria Manelli 2001, p. 102; A. Del Noce, Il problema dell'ateismo, p. 33.

5 A. Del Noce, Il problema dell'ateismo, pp. 138, 255.

6 A. Del Noce, Rivoluzione, risorgimento, tradizione. Scritti su "L'Europa" (e altri, anche inediti), eds. F. Mercadante, A. Tarantino, B. Casadei, Milano 1993, pp. 432-433. 
an anti-rational mentality, and the Gentile's irrationalization of Hegelian philosophy $^{7}$; historically, an attempt to overcome, much less than oppose, the Bolshevik revolution. ${ }^{8}$

Del Noce's analysis starts from the concept of Modernity, which he tries to define with rigor, in order to fully understand all the philosophical consequences of secularization, and especially in reference to totalitarianism. For Del Noce, the modern age is the historical era marked by rationalism, the philosophical mood that rejects all forms of transcendence, on which most of the philosophical theories of recent centuries converge. ${ }^{9}$ The necessary and more logical outlet of rationalism is atheism. ${ }^{10}$ It reaches an unsurpassed philosophical form with Marxism. ${ }^{11}$ Hence the centrality of the philosophy of Marx, his success and his failure, in contemporary history.

For Del Noce, rationalism is based on a practice of "rejection without evidence" 12 of the biblical concept of $\sin$, the concept of idea of status naturae lapsae. ${ }^{13}$ This unheard of initial choice, on which modernity is based, is the most important theoretical postulate from which the atheistic project is developed and of which totalitarianism is an essential moment, even if not a final one. This is because, writes Del Noce, there are only two explanations to the problem of Evil: that of the Bible, and that contained in the fragment of Anaximander, as interpreted by Nietzsche. According to the Judeo-Christian tradition, there is an "infinite qualitative difference between Creator and human creation", which "allows us to speak of communion, but not of substantial union" between the whole and the part; and "the concept of creation excludes" that "the root of Evil lies in the finite nature of humans".14

Hence, the value of the individual as a person, and freedom, perceived first of all, as free will. On the contrary, the Eastern spirit, condensed in the fragment of Anaximander, "is characterized by the concept of finite individuality as Evil and the consequent aspiration to total fusion with the divine". ${ }^{15}$ Now, the

7 A. Del Noce, Il problema dell'ateismo, p. 155.

${ }^{8}$ Because of these aspects, Del Noce believes that Fascism cannot be categorized into the same type of Nazism and Communism, but is another type: A. Del Noce, Giovanni Gentile..., p. 158. However, in considering Fascism as a form of totalitarianism, Del Noce is distancing himself from Scholars such as Hannah Arendt and Domenico Fisichella, who classified Fascism as an authoritarian regime. Ibid., p. 333. See H. Arendt, The Origins of Totalitarianism, New York 1951; D. Fisichella, Totalitarismo. Un regime del nostro tempo, Roma 1992. These aspects are analyzed by R. Pezzimenti, "Il totalitarismo nell'analisi di Augusto Del Noce", [in:] Augusto Del Noce filosofo politico, ed. T. Dell'Era, Soveria Mannelli 2000, pp. 101-117.

9 A. Del Noce, Il problema dell'ateismo, pp. 17-18.

10 Ibid., pp. 9-10.

11 Ibid., p. 22.

12 Ibid., p. 40.

13 Ibid., p. 24.

14 Ibid., p. 172. See also A. Del Noce, Giovanni Gentile..., p. 114.

15 A. Del Noce, Il problema dell'ateismo, p. 172. 
denial of transcendence and the consequent rejection of the idea of the Fall, means that the problem of Theodicy becomes necessarily - this point of view was stated for the first time by Rousseau ${ }^{16}$ — of political significance and equally strictly imposes a solution through politics; because if the only human thinking is that of materiality, the "return to All" proposed by Eastern Theodicy can only mean the nullification of individuality, perceived as an Evil, in the political community and the cancellation of the single in the All, in the State.

Hence, the Marxist utopia of social man - a topic which all totalitarian ideologies developed ${ }^{17}$ — as a human who will overcome not only the bourgeois, but also of the individual Christian, "because of that connection between finite individuality and Evil, which is the precondition of rationalism, as a denial of Creation and the Fall". 18 This also explains why Communism, theorized by Marx in the West, according to the Eastern view of Evil, found its practical application in the East. ${ }^{19}$

In addition, from here it follows that the transformation of man is no longer conceived as a spiritual moment, the result of the meeting of a free action of man as an individual with the divine Grace; but it is thought of, from a purely immanent perspective, as the result of a radical transformation of society, with the totalitarian implication that "the relationship of persuasion", on which the religious transformation of man is based, is replaced by a "relationship of violence". ${ }^{20}$

Not only this: from this postulate also comes the idea of the revolution as an earthly redemption tool, which allows the neo-Gnostic leap from the world of the false god in the world of the true God, and the attribution to man of "divine creative freedom". ${ }^{21}$ The latter is a theme which was developed in particular by German classical philosophy and taken to the most extreme and consistent consequences in Marx's philosophy. Marx, in fact, conceived politics as the "highest activity" as "philosophy in action", in order to radically transform the world and change human nature. 22

In Marx's thinking, Del Noce writes - in disagreement with Hannah Arendt — the problem of God is really central, and one could say that his whole philosophy is a form of negative theology, in which "the future replaces the Lord,

${ }^{16}$ Del Noce quoted the works on this subject of S. Cotta, philosopher of Law who underscored the Pelagian theodicy of Rousseau. See S. Cotta, I limiti della politica, Bologna 2002, pp. 225-262. These points were also emphasized by E. Cassirer, Il problema Gian Giacomo Rousseau, Firenze 1938; and J.F. Thomas, Le pélagianisme de J.J. Rousseau, Paris 1956.

17 A. Del Noce, Il suicidio della rivoluzione, Milano 2012, p. 37.

18 A. Del Noce, Il problema dell'ateismo, p. 514.

19 Ibid., p. 172.

20 A. Del Noce, Il suicidio della rivoluzione, p. 37.

21 Ibid. The interpretation of totalitarianism as a form of Gnosis is expanded upon, above all, by L. Pellicani, Lenin e Hitler. I due volti del totalitarismo, Soveria Mannelli 2009; idem, La società dei giusti. Parabola storica dello gnosticismo rivoluzionario, Soveria Mannelli 2012.

22 A. Del Noce, Il suicidio della rivoluzione, p. 40. 
and Wholeness the Absolute and the City of God". 23 "The final transformation of the realm of necessity into the realm of freedom corresponds to the transformation of the earthly city into the city of God". 24

The historical realization of Marxism, says Del Noce, could only take place, in the $20^{\text {th }}$ Century, in the form of Leninism, i.e., returning to Hegelian origins, after the crisis of Marxism at the end of the century. ${ }^{25}$ Del Noce comes to affirm that Lenin was "the first one to really understand Marx", ${ }^{26}$ because he realized that Marx's philosophy was to be the "creation of a whole". ${ }^{27}$ In Del Noce's view, Leninism is an heir of Marxism more than the last expression of Russian revolutionary tradition, as many scholars have otherwise stated. ${ }^{28}$ Lenin was a "true Marxist" ${ }^{29}$ who, by establishing the primacy of philosophical and political dimension, ${ }^{30}$ managed to dissolve the ambiguity contained in early Marxism, which at the same time claimed to represent the consciousness of the proletariat, and the endpoint of German classical philosophy. ${ }^{31}$ In Russia Communist ideology arose as "development of thinking among the revolutionary socialist intellectuals", and not as a spontaneous growth of the labor movement. ${ }^{32}$

However, the October Revolution, which aspired to becoming a world revolution, ended "in the face of the reality of nations. As a realistic acceptance of this ending, the figure of Stalin stood out". Stalinism must therefore be interpreted as "the form that Communism had to adopt, in order to survive, in an ideologically hostile world": 33 once again, coherently applying Marxist-Leninist philosophy.

In the reconstruction of the origins and development of totalitarian ideologies, a notable part of Del Noce's works is dedicated to the analysis of Fascist doctrine, especially the study of Giovanni Gentile's thinking, paradigmatic of the encounter between philosophy and totalitarianism. Here the revisionism of Del Noce can be found in the fact that he rejects one of the most important postulates of Italian left-wing historiography: the interpretation of Fascism as an anti-cultural movement. ${ }^{34}$ To support this view, historians of the Resistance had to invent a caricatured reinterpretation of Fascism, concealing, for example, the fact that

23 A. Del Noce, Il problema dell'ateismo, p. 298.

24 Ibid., p. 112.

25 Ibid., p. 108.

26 Ibid., p. 251.

27 Ibid., p. 247.

28 Ibid., p. 169.

29 Ibid., p. 253.

30 Ibid., p. 168.

31 Ibid., p. 164.

32 Ibid., p. 168.

33 Ibid., p. 159.

34 A. Del Noce, Giovanni Gentile..., p. 285. 
the "greater part" of Italian intellectuals, secularists and Catholics, "had for some time, been sympathizing with Mussolini". ${ }^{35}$

With particular reference to Gentile, Del Noce highlights how the anti-Fascist culture, which arose in the same milieu of anti-Fascism, the democratic pro-World War I coalition, and which was mainly an offspring on a philosophical level of Italian neo-idealism, was forced to artificially separate Gentile the philosopher, who was worthy of a positive assessment, from Gentile the fascist politician, considered a traitor of his own thought; or to force interpretation of Gentile's fascism in a liberal sense; or even to consider Gentile as a symbol of reactionary Italy. ${ }^{36}$

The truth, however, is quite different, because in Gentile's way of thinking Del Noce writes - we can find "a complete inseparable unity of the philosopher and the religious and political reformer" and a "remarkable coherence in its theoretical and practical activities": ${ }^{37}$ a coherence between pre-Fascist and Fascist thought and political activity of Gentile. "Fascism succeeded in Italy [...] because in the early years of the $20^{\text {th }}$ Century the top layer of Italian culture [...] was represented by Gentile, who provided the Fascism of a unitary ideology which failed in the French movements". 38 Such unity consisted on the one hand, of a vision in which the religious, the political and the philosophical element were holistically merged into an inextricable whole and on the other, in claiming to be the higher synthesis, in a Hegelian sense, of the best parts of Italy's Risorgimento and pre-Fascist institutions. This was an aspect which provided a theoretical justification for political compromises that Fascism made with the monarchy, the Church and other institutions. These compromises conferred a peculiar character to Fascism, different and less extreme than Nazism and Communism. It is the theme of Fascism as an imperfect totalitarianism, later developed by De Felice.

Del Noce shows how Fascism's ambition to be both a conservative and revolutionary movement was one of the most important themes developed by Gentile in his pre-Fascist works. ${ }^{39}$ On a philosophical level, on a historiographical level and finally as a militant journalist, Gentile, between the end of the $19^{\text {th }}$ Century and the 1920s, developed a philosophical, religious and political doctrine, which subsequently and consistently merged into Fascism, significantly contributing to connote its ideology and even its policies.

On a philosophical level, Gentile devised a neo-idealist version of Hegelianism ("attualismo"), which, marked by absolute immanentism, is characterized by "the refusal of reality": 40 "empirical subjects become transient instruments", ${ }^{41}$ and God,

\footnotetext{
35 Ibid., p. 148.

36 Ibid., p. 290.

37 Ibid., pp. 11-12.

38 Ibid., p. 13.

39 Ibid., pp. 298-299.

40 Ibid., p. 31.

41 Ibid., p. 33.
} 
or universal thought, is the immanent being in every sentient being, which exists as it creates itself in a process called "autoctisi" (self-creation). ${ }^{42}$ Its essence is the continuous transformation of reality. Del Noce considers the following to be perfect:

the conformity [...] with Fascism, which is nothing but the absolute activism transplanted in the field of politics and with the new revolutionary spirit, in which the action becomes absolute value but with no content, in a way that it is done for the sake of the action, so its purpose becomes the destruction of reality. ${ }^{43}$

However, there is another important fact to bear in mind. In 1898 Gentile develops his version of the philosophy of praxis, through a critical review of Marxist philosophy, with a text, Marx's philosophy, in which, according to Del Noce, we can find "the first root of Fascism". ${ }^{44}$ Here Gentile intended to purify Marxist dialectical philosophy from materialism, maintaining radical immanentism. Del Noce observed that the praise bestowed to this work by Lenin, a fiercely anti-idealist thinker, can be explained by the fact that Lenin was interested, at that time, in re-establishing "the connection between Marxism and Hegelianism", ${ }^{45}$ to enshrine in Marxism "the primacy of philosophical moment" ${ }^{46}$ But Gentile also drew from Marx another concept later developed by Fascism, the idea "that the individual as such is not real, but only the social being is real". ${ }^{47}$

Even the writings of Gentile regarding Risorgimento's thinkers show that his judgment "on the Risorgimento, connected with his interpretation of Italian history in its entirety, was already fully-formed well before his adhesion to Fascism". 48 They also reveal one of the most contradictory aspects of Fascism: in fact, Del Noce writes,

the philosophy founded on the primacy of action means desecration of tradition and the creation of the new man, compared to which all past history becomes prehistory: the past becomes bad. Hence that strange union of activism and subversive spirit, and conservatism, that characterizes actualism. ${ }^{49}$

Finally, in his journalistic writings Gentile elaborated a different justification of the war from the democratic interventionist: the war is presented by Gentile as a moral purification from the disease contracted by the Italians with the reformist policy of Giolitti. ${ }^{50}$ Gentile enunciated the principle that nations are not natural

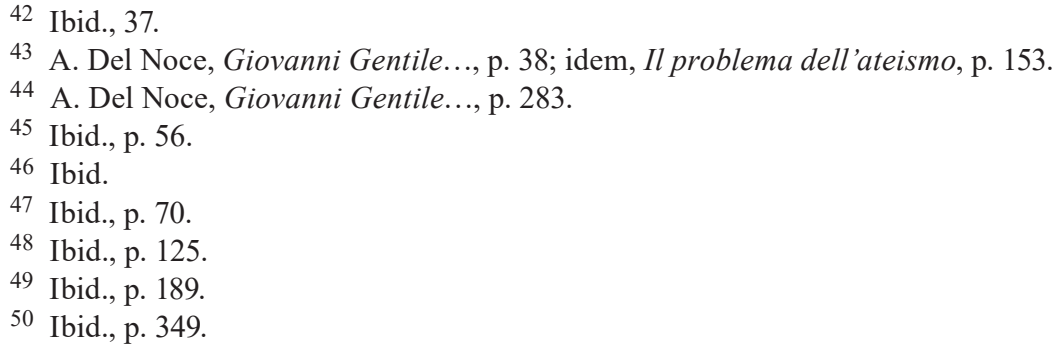


entities, it is necessary to build them, and in the founding of new empires the State's will to power is expressed, necessarily, in policies of conquest. This principle, observes Del Noce, inspired the wars of Mussolini and particularly that of Ethiopia, the start of the "European civil war", which culminated in World War II. ${ }^{51}$

It is not surprising, therefore, that, despite coming from different cultural traditions, between Mussolini and Gentile there settled "a kind of dialectical inseparability, without which the consolidation of Fascism would remain inexplicable". 52 Gentile thus came to draw up the doctrine of Fascism "without swerving in the slightest from his thinking": "in it he [...] perfectly defines the character of Fascist totalitarianism, for that which is distinguished from Communism and Nazism". The Fascism of Gentile corresponded exactly with that of Mussolini ${ }^{53}$ because it came to the same conclusions, although the starting point was different. ${ }^{54}$

Gentile composed the doctrine of Fascism 55 "without deviating from his thought": "in that doctrine (he) perfectly defines the nature of Fascist totalitarianism, as it distinguishes itself from Nazism and Communism". ${ }^{56}$ Gentile shared with Mussolini - in what is one of the peculiarities of Fascism, compared to Communism and Nazism ${ }^{57}$ - the idea of the primacy of the State over the Party and the Nation, the latter being the product of political and pedagogical voluntarism, ${ }^{58}$ whose aim is to achieve "the total unity of the Italians". 59

Now, taking into account this

'appearance of philosophical revolution' which coincides with the transition towards a 'philosophy of praxis', which is clearly anti-individualist, critical of bourgeois Liberalism, social-reformism and religious transcendence, we can easily appreciate the enthusiasm they felt at the beginning, for Gentile's philosophy, the 'Ordine Nuovo's young Communists, the founders of the Italian Communist Party. ${ }^{60}$

Del Noce's revisionist interpretation of the Fascist phenomenon engages, as anticipated, anti-Fascist culture, and in particular the political philosophy of Antonio Gramsci, presented by Italian Communists, for many years, as evidence of the diversity of Italian Communism from Stalinism. Of course, observes Del Noce, Gramsci's Marxism is different from Sovietic-leninism, not as anti-totalitarian, but because it reveals nothing but the "revolutionary version of Gentile's

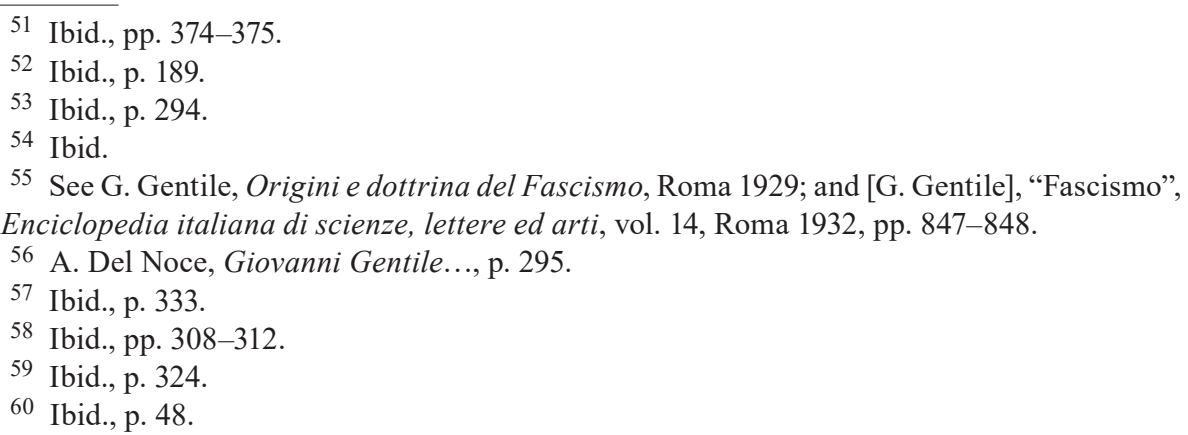


actualism". 61 The revolutionary transformation of society as described by Gramsci, in fact overturns the Marxist dialectic structure/superstructure even more than Lenin's does, assigning to the revolutionary pedagogy the task of bringing the Communist party in Italy to exercise cultural hegemony and political dominance. This means the overcoming of Marxism in the sense of developing a philosophy of praxis purified by materialism; an operation, of course, similar to that achieved in previous years by Gentile.

The result is that Gramscism, according to Del Noce, has to be considered as a "continuation of Fascism in the process of destruction of reality". 62 This doctrine has even more totalitarian traits than Stalinism. First, it is to be noted that, like Gentile, Gramsci uses the term totalitarianism in a clearly positive sense. ${ }^{63}$ His political discourse remains entirely within totalitarianism, even lexically: in fact, Gramsci does not denounce Fascism because it is totalitarian, but accuses it of having "falsified the sense" of the term. ${ }^{64}$ For Gramsci, the real opposition is not between freedom and dictatorship, but between real and unreal totalitarianism. ${ }^{65}$ As well as this, Gentile's actualism served as a bridge between the Hegelian dialectic and Gramscism, through the dissolution of Marxism as a materialist philosophy; so Gramscism turned out, for Del Noce, to be the ideology that ferried the scholars of Croce and leftist fascists, who were the most totalitarian, towards anti-Fascism and would thus be able to proceed in disguising their ruthless struggle against liberal society. 66

In conclusion: I would like to underline an unresolved problem in the philosophical interpretation of contemporary history shown by Del Noce, which is more rigorous and deeper than the many others developed in Italy in the second half of the $20^{\text {th }}$ Century, that consequently involves and perhaps compromises his analysis of totalitarianism.

The philosophical reconstruction of Del Noce, is in fact focused on the dichotomy between theism and atheism. Modernity is identified tout court with the rationalist rejection of the concept of original sin, from which atheism and totalitarianism necessarily follow, the latter being as an essential and necessary moment in the process of atheization of society. The assumption on which this interpretation is founded, however, is questionable, in that it is reductive.

First of all, one could observe that, starting with the Enlightenment, a large part of the political tradition of reformism - liberal and then democratic-social-

61 A. Del Noce, Il suicidio della rivoluzione, p. 57.

62 Ibid., p. 140.

63 Ibid., p. 140.

64 From this point of view, Gramsci could be considered the first "revisionist" of Fascism, since he wrote that Mussolini's regime was an imperfect form of totalitarianism. See A. Gramsci, Quaderni del carcere, vol. 2. Quaderni 6-11 (1930-1933), ed. V. Gerratana, Torino 2001, p. 800.

65 A. Del Noce, Il suicidio della rivoluzione, p. 78.

${ }^{66}$ Ibid., p. 144. 
ist - elaborated a secularized version of the Bible's conception of the Fall, which could be symbolized by the Kantian image of humanity as "crooked timber". This is that form of "moderate rationalism" that Del Noce, as Bobbio says, must cross out from the history of philosophy, with the purpose of corroborating his dichotomous scheme. ${ }^{67}$

Secondly, Del Noce equates the concept of modernity with that of atheism. For him individual freedom, with which modernity could otherwise be identified, depends on the concept of transcendence, so that "true" freedom seems possible and thinkable only in a Christian society. This approach leads him to some paradoxical and contradictory positions.

Liberty, in the first place, is identified with a kind of submission: the submission of man to the principle of divine transcendence, the only act which makes the triumph of reason over passions and of the spirit over matter possible. "True" Liberalism, according to Del Noce, would be recognized thanks to the principle of transcendence, rather than that of freedom, ${ }^{68}$ focused on a concept of "positive" freedom instead of "negative" 69 and finally it is shown to be almost incompatible with economic freedom. ${ }^{70}$

In this reconstruction, modernity is not opposed to totalitarianism, ${ }^{71}$ which in fact is presented by Del Noce, in agreement with the authors of the Frankfurt School - which are explicitly appreciated by the Italian philosopher for the pars destruens $^{72}$ - as an epiphenomenon of a larger process, specifically as the moment that a theocentric society becomes anthropocentric, and in particular the moment when atheism, not yet fully mature, is still forced to assume the guise of a religion, even if it is political.

67 N. Bobbio, "Del Noce: Fascismo, Comunismo, Liberalismo", [in:] Aa.Vv., Augusto Del Noce..., p. 183. With regard to this aspect, you can reflect on critical considerations of D. Settembrini, "Borghesia, Liberalismo e Fascismo", in the same book (pp. 127-163).

68 In this manner, the Italian philosopher appears to propose again the old polemic of Croce and Gentile against Anglo-Saxon empiricist Liberalism in the name of true moral Liberalism, derived from German classical philosophy. A. Del Noce, Rivoluzione, risorgimento, tradizione..., pp. 154, 530-531. Yet the same Del Noce had pointed out the uncertain Liberalism of the young Gentile. See A. Del Noce, Giovanni Gentile..., p. 319.

69 A. Del Noce, Rivoluzione, risorgimento, tradizione..., p. 531. On this see I. Berlin, Two Concepts on Liberty, London 1958.

70 A. Del Noce, Il problema dell'ateismo, p. 539.

71 The relationship between modernity and totalitarianism, with particular reference to the argumentations of the Frankfurt School thinkers and Del Noce, see L. Pellicani, "Modernità e totalitarismo", [in:] Dimensioni della modernità, ed. L. Pellicani, Fornello (RM) 1999, pp. 9-37.

72 Del Noce especially agrees with M. Horkheimer, T.W. Adorno, Dialettica dell'illuminismo, Torino 1971; M. Horkheimer, La nostalgia del totalmente altro, Brescia 1972; idem, Eclisse della ragione, Torino 1975. See A. Del Noce, Rivoluzione, risorgimento, tradizione..., pp. 267, 363, 453, 555; idem, "Eric Voegelin e la critica dell'idea di modernità", [in:] E. Voegelin, La nuova scienza politica, Torino 1968, p. 32; idem, "Prefazione", [in:] M. Veneziani, Processo all'Occidente, Milano 1990, p. 12. 
More than anything, with the passing of the years, Del Noce exacerbated his criticism of contemporary society and extended the concept of totalitarianism to Western open societies, so that ultimately the whole of contemporary history is, in his view, marked with the signs of totalitarianism.

With a lexicon based on moralism and political hyperbole, Del Noce blames a liberal-democratic society, which wins the long confrontation with totalitarianism. Del Noce describes democracy as a technocratic society that is in a relationship of substantial continuity with totalitarianism, achieving, in many respects, a more subtle and pervasive form of totalitarianism: worse, definitely, than Nazism and Communism ${ }^{73}$ since it produces an unprecedented alienation and reification of the human being, ${ }^{74}$ due to the annulment of his spirituality, ${ }^{75}$ the transformation of everything in an object of exchange, ${ }^{76}$ and the dominance of economic powers. ${ }^{77}$ Above all, the new totalitarianism radically destroys the Tradition. ${ }^{78}$ When this society not only denies God and his sovereignty, ${ }^{79}$ but also does not perceive it as a problem ${ }^{80}$ and when it reduces man to pure materiality - a "bundle of needs that must be satisfied" 81 — open to all sorts of manipulation by the instrumental reason on which contemporary society is based, ${ }^{82}$ liberal democracy degenerates into permissive, libertarian and opulent societies, broken up by a mass libertinism. ${ }^{83}$ This society can be recognized as "intrinsically totalitarian" 84 . In the same way, the difference between liberal democracy and totalitarianism, which Del Noce clearly pointed out in his earlier works, is annulled. ${ }^{85}$ Contemporary democracy is no longer liberal: ${ }^{86}$ briefly, liberal democracy becomes for Del Noce the political system that, after defeating Marxism, makes in another form its atheistic dream

73 You can find this judgment, for example, in A. Del Noce, Rivoluzione, risorgimento, tradizione..., p. 354; idem, Modernità. Interpretazione transpolitica della storia contemporanea, Brescia 2007, p. 79; idem, "Eric Voegelin...", p. 13.

74 "Western society is characterized by a total exploitation of man, which is turned into an instrument; and this reification of man overturns the premises of westernization" - A. Del Noce, "Prefazione", p. 9. See also idem, Il problema dell'ateismo, pp. 310, 319; idem, L'epoca della secolarizzazione, p. 64.

75 A. Del Noce, Rivoluzione, risorgimento, tradizione..., p. 560.

76 A. Del Noce, L'epoca della secolarizzazione, p. 87.

77 A. Del Noce, Rivoluzione, risorgimento, tradizione..., p. 135.

78 Ibid.

79 Ibid., p. 528.

80 A. Del Noce, Il suicidio della rivoluzione, p. 294; idem, L'epoca della secolarizzazione, p. 109.

81 A. Del Noce, Il suicidio della rivoluzione, p. 319.

82 "New" totalitarianism 'preserves essential features' of the "old" one, among which 'the extinction of the individual' — A. Del Noce, Rivoluzione, risorgimento, tradizione..., p. 131.

83 Ibid., pp. 61-95.

84 A. Del Noce, L'epoca della secolarizzazione, p. 27.

85 A. Del Noce, "Lo Stato totalitario", [in:] idem, Scritti politici 1930-1950, p. 39.

86 A. Del Noce, L'epoca della secolarizzazione, p. 85. 
come true. ${ }^{87}$ If, on the one hand opulent society is the mirror of the triumph of individualism over Communism, Stirner's posthumous victory over Marx ${ }^{88}$ on the other can be evaluated as a form of Marxism's fulfilment.

But the most compromised concept elaborated by Del Noce appears that of totalitarianism. In fact, he recalls some of the classical definitions of totalitarianism, such as that of Friedrich and Brzezinski, ${ }^{89}$ but fills them with partially different contents, changing their meaning. Totalitarianism is defined by Del Noce on the basis of his relationship with religion and only later on the basis of his relationship with freedom, becoming the regime that pursues true religion. "Totalitarianisms", in fact, "have their roots in a certain way of conceiving political functions in the life of the spirit". According to Del Noce, the opposite of totalitarianism is not Liberty, but Authority, which is the Tradition on which the "true" Liberty depends. ${ }^{90}$ The tragedy of modern society, the transition from theocentric to anthropocentric society, the birth and development of atheism and totalitarianism, must be explained by the conflict between Authority and Power, not between Authority and Liberty. ${ }^{91}$

Totalitarianism is really a new phenomenon in history, ${ }^{92}$ because the eclipse of the principle of authority that has made its genesis possible is new, and not by chance in totalitarian regimes Power is maximized, whereas Authority is minimized..$^{93}$ Theocracy is explicitly defined as the regime opposed to totalitarianism, since it establishes a relationship of total subordination of politics to religion, where totalitarianism pursues the exact opposite goal. ${ }^{94}$

Finally, the fact of taking a unique key concept to analyze the development of thought and society seems therefore to lead Del Noce to a paradoxical outcome, in which modernity is confused with anti-modernity. Not only this, but also, and more seriously, freedom with totalitarianism.

${ }^{87}$ For Del Noce, Western society is realizing the whole atheist program of Marxism, except for the abolishment of alienation and the messianic faith in the Revolution, the only joining links between revolutionary thought and traditional religion. See A. Del Noce, Rivoluzione, risorgimento, tradizione..., p. 8. See also idem, Il problema dell'ateismo, p. 176; idem, Modernità ..., p. 21. Under this point of view, Del Noce finally evaluates Marxism in the phase of "transition between one level of bourgeoisie and the other" - ibid., p. 7.

88 A. Del Noce, Modernità..., p. 66.

89 A. Del Noce, Il suicidio della rivoluzione, p. 82. See C.J. Friedrich, Z. Brzezinski, Totalitarian Dictatorship and Autocracy, Cambridge 1956.

90 Del Noce thinks that totalitarianism is a refusal of Liberty because it refuses authority. See A. Del Noce, Rivoluzione, risorgimento, tradizione..., p. 519.

91 Ibid., p. 577.

92 A. Del Noce, Il problema dell'ateismo, p. 257; idem, Il suicidio della rivoluzione, p. 34.

93 A. Del Noce, Rivoluzione, risorgimento, tradizione..., p. 559; idem, Il suicidio della rivoluzione, p. 32. See also idem, "Eric Voegelin”, p. 13.

94 A. Del Noce, Rivoluzione, risorgimento, tradizione..., p. 531. 
Though it is capable of casting light on some unsettling trends of his and our age, the analysis of totalitarianism drawn up by the Italian philosopher is perhaps overwhelmingly influenced by the libertarian counterculture of the 1960s and ends with a focus on the most peculiar feature of totalitarianism: the complete occupation of society by the State, the pervading desire of the State to erase the individual - which is conceivable as the holder of inalienable rights and in particular of the negative freedoms only within modern Liberalism: a rebellious, but not illegitimate son, of the Judeo-Christian tradition, so rightly dear to Augusto Del Noce.

\section{Bibliography}

Aa.Vv. 1995. Augusto Del Noce. Il problema della modernità. Roma: Studium.

Arendt, H. 1951. The Origins of Totalitarianism. New York: Harcourt, Brace.

Berlin, I. 1958. Two Concepts on Liberty. London: Clarendon.

Cassirer, E. 1938. Il problema Gian Giacomo Rousseau. Firenze: La Nuova Italia.

Cotta, S. 2002. I limiti della politica. Bologna: Il Mulino.

De Felice, R. 2011. Fascismo. Firenze: Le Lettere.

Del Noce, A. 1968. "Eric Voegelin e la critica dell'idea di modernità". In: E. Voegelin, La nuova scienza politica. Torino: Borla.

Del Noce, A. 1989. Secolarizzazione e crisi della modernità. Napoli: Istituto Suor Orsola Benincasa.

Del Noce, A. 1990a. Giovanni Gentile. Per una interpretazione filosofica della storia contemporanea. Bologna: Il Mulino.

Del Noce, A. 1990b. "Prefazione". In: M. Veneziani, Processo all'Occidente. Milano: SugarCo.

Del Noce, A. 1993. Rivoluzione, risorgimento, tradizione. Scritti su "L'Europa" (e altri, anche inediti), eds. F. Mercadante, A. Tarantino, B. Casadei. Milano: Giuffrè.

Del Noce, A. 2001. Scritti politici 1930-1950, ed. T. Dell'Era. Soveria Manelli: Rubbettino.

Del Noce, A. 2007. Modernità. Interpretazione transpolitica della storia contemporanea. Brescia: Morcelliana.

Del Noce, A. 2010. Il problema dell'ateismo. Bologna: Il Mulino.

Del Noce, A. 2012. Il suicidio della rivoluzione. Milano: Il corriere della Sera.

Dell'Era, T. (ed.). 2000. Augusto Del Noce filosofo politico. Soveria Mannelli: Rubbettino.

Fisichella, D. 1992. Totalitarismo. Un regime del nostro tempo. Roma: Nis.

Friedrich, C.J., Brzezinski, Z. 1956. Totalitarian Dictatorship and Autocracy. Cambridge: Harvard University Press.

Gentile, G. 1929. Origini e dottrina del Fascismo. Roma: Libreria del Littorio.

[Gentile, G.]. 1932. "Fascismo". In: Enciclopedia italiana di scienze, lettere ed arti, vol. 14. Roma: Istituto della Enciclopedia italiana fondata da Giovanni Treccani.

Gramsci, A. 2001. Quaderni del carcere, vol. 2. Quaderni 6-11 (1930-1933), ed. V. Gerratana. Torino: Einaudi.

Horkheimer, M. 1972. La nostalgia del totalmente altro. Brescia: Queriniana.

Horkheimer, M. 1975. Eclisse della ragione. Torino: Einaudi.

Horkheimer, M., Adorno, T.W. 1971. Dialettica dell'illuminismo. Torino: Einaudi.

Pellicani, L. (ed.). 1999. Dimensioni della modernità. Fornello (RM): Seam. 
Pellicani, L. 2009. Lenin e Hitler. I due volti del totalitarismo. Soveria Mannelli: Rubbettino.

Pellicani, L. 2012. La società dei giusti. Parabola storica dello gnosticismo rivoluzionario. Soveria Mannelli: Rubbettino.

Thomas, J.F. 1956. Le pélagianisme de J.J. Rousseau. Paris: Nizet.

\section{AUGUSTO DEL NOCE AND THE PROBLEM OF TOTALITARIANISM}

\section{Summary}

The aim of this paper is to present the reflections of the Italian philosopher Augusto Del Noce (1910-1989) on totalitarianism and highlight some of the problems that this perspective can lead to in the analysis of the totalitarian phenomenon. Del Noce originally developed a philosophical and transpolitical interpretation of modernity, secularization and totalitarianism, pre-empting, in the early 1960s many of the arguments developed later by "revisionist" scholars: Fascism was an imperfect form of totalitarianism; Nazism was a reaction to Communism; Communism was the most perfect example of the totalitarian State. The philosophical reconstruction of Del Noce is focused on the dichotomy between theism and atheism. Modernity is identified tout court with the rationalist rejection of the concept of original sin, from which atheism and totalitarianism necessarily follow, the latter being as an essential and necessary moment in the process of atheization of society. The assumption on which this interpretation is founded, however, is questionable, in that it is reductive.

Keywords: Augusto Del Noce, totalitarianism, Modernity, Liberty, Giovanni Gentile, Antonio Gramsci.

Francesco Berti

francesco.berti@unipd.it 